\title{
Secrecy and Sustainability: How Concealment and Revelation Shape Vepsian Language Revival
}

\section{Laura Siragusa University of Aberdeen}

\begin{abstract}
In this article, I explore questions related to language sustainability, examining whether secrecy practices, both in written and oral form, support or hinder language revival. Within cultural anthropology, secrecy often reflects "epistemological and ethical dimensions" of the researcher and research institutions. The work presented in this article adds to this already-existing definition, providing an understanding of secrecy as an ontological practice. Stemming from fieldwork with Veps in northwestern Russia, this research demonstrates how secrecy fosters the sustainability of the Vepsian language, moving it from simply being used as a means for protecting and overcoming the challenges to Vepsian generational transmission. This change is reflected in the differences between literacy and orality.
\end{abstract}

Keywords: secrecy, language sustainability, literacy and orality, Vepsian heritage language, ontology of concealment practices, new technologies

Résumé : Dans cet article, je traite de questions liées à la durabilité linguistique et examine si les pratiques de secret, sous forme écrite et orale, favorisent ou entravent le renouveau linguistique. En anthropologie culturelle, le secret reflète souvent des «dimensions épistémologiques et éthiques " du chercheur et des institutions de recherche. À cette définition déjà existante, s'ajoute ici une explication du secret comme pratique ontologique. Issue d'un travail de terrain auprès des Vepses du nord-ouest de la Russie, cette recherche démontre que le secret favorise la durabilité de la langue vepse, au-delà du simple outil de protection contre les pertes de la transmission générationnelle. Ce changement se constate dans les différences entre l'écrit et l'oral.

Mots-clés : secret, durabilité linguistique, écrit et oral, langue de patrimoine Vepse, ontologie des pratiques de dissimulation, nouvelles technologies.

74 / Laura Siragusa

\section{Introduction}

Qecrecy, adopted as a social, shared exercise, came to Dmy attention during the first few days of my 2009 fieldwork. It was not only among Veps, a Finno-Ugric minority of northwestern Russia, that I noticed the behaviour but also often among Russians living in this territory (see Figure 1). As I was getting to know people and they were sharing stories about their lives and daily habits, I regularly heard statements such as: "I will tell you a secret" and "Do not tell anyone. It's a secret!"1 During my fieldwork, these remarks occurred frequently (and still do). Such secretive remarks were made by people of different ages, living in both urban and rural settings. However, what appeared to differ is the way that younger and older, urban and rural Veps engaged in concealment practices with oral and written bilingual behaviours (such as code-switching), which also revealed multiple ontological and political dynamics in their language choice.

The Vepsian language is a minority language of the Russian Federation and is classified as seriously endangered by the UN Educational, Scientific and Cultural Organization. Despite language revival efforts that began in the mid-1980s in the Republic of Karelia, the number of Vepsian speakers continues to drop, and the census carried out in 2010 showed that only 3,613 out of 5,936 individuals reported having some kind of competence in their heritage language (Puura et al. 2013, 18; Strogal'shchikova 2013). In this northern region, women outnumber men, and they are often the ones to determine the preservation of or change in social behaviours (Strogal'shchikova 2008). During my fieldwork, I observed that Vepsian elderly villagers (those older than 60 ) tended to be bilingual in their own Vepsian dialect and Russian, whereas Vepsian urbanites tended to speak Russian in their daily life and to use Vepsian in those settings where their heritage language is promoted. Vepsian village dwellers often switch between Russian and Vepsian 
depending on the existent language ecology. My understanding of language ecology matches that developed by Peter Mühlhäusler (2000) and Mark Garner (2004), who view language use as the result of mutual relations with the main forces present in a place at a specific time. These also comprise language ideologies and attitudes (Woolard and Schieffelin 1994). In other words, humans engage (or not) in communication practices often depending on the place of verbal and/or written interaction (Ahearn 2001; Heath 1983; Sebba 2013; Wedin 2013); on their interlocutor(s) (Ferguson 1959); on the topic of discussion; on prevailing socio-cultural ideologies (Ferguson forthcoming); and so on. ${ }^{2}$ Talking about school education and work, for example, might prompt the use of Russian among Vepsian elderly speakers since this was the language that they mostly spoke in those places; yet they might predominantly speak Vepsian when talking about their daily activities. I should also point out that most of them cannot read or write in Vepsian due to a history of oppression that did not enable them to develop those skills. As a result of the revival efforts and dynamism of this located language ecology, Vepsian code-switching practices have more recently encompassed further domains. Indeed, those Veps who have received an education in Vepsian literacy, mostly urban Veps in their late-twenties and mid-thirties, also engage in code-switching written practices. ${ }^{3}$

This article discusses the concealment practices of Veps, both in written and oral form, examining whether these practices support or hinder the revival of the Vepsian language. I will present two main dynamics to demonstrate the way that language epistemology and ontology intersect with a vexed political history of ethnic persecution. The word "ontology" here refers to the production of knowledge and its perception while interacting with the environment and other human and nonhuman agents. The first dynamic refers to those bilingual speakers for whom code-switching into Russian has become a register of avoidance and Vepsian is re-signified as a language of power or sacredness (compare to Debenport 2015; Kulick 1992). The second dynamic shows how the Vepsian language can be used to shield information from Russian monolinguals, which more directly hints at a political awareness of social inequality. These two dynamics - that is, the ontological aspect of secrecy tinted with political shades - have recently found a new expression among younger Veps who now also engage in concealment written practices within social network sites.

I will start the article by providing a description of Vepsian language ecology as well as a historic-political synopsis of the Vepsian revival movement to contextualise relations of power inequality. I will then describe in more depth the way that language ontology and secrecy are embroiled in these complex socio-political relations. This section will be followed by a discussion on the use of Vepsian as a medium of concealment and the revelation of concealment in social media. As a result, I hope this work will contribute to the discussion on new media and language revitalisation (to name a few on this topic, see also Cook 2004; Eisenlohr 2004; Kaplan and Haenlein 2010; Moore and McElroy 2012).

\section{The Research: Vepsian and Language Sustainability}

Vepsian traditional settlements occupy a vast area at the periphery of the Republic of Karelia, Leningrad, and Vologda Oblasts (see Figure 1) (Puura et al. 2013). This northern territory is multi-ethnic and multilingual given that Veps, Karelians, Russians, Ingrians, and so on live here, which is one of the reasons why people employ Russian as a lingua franca, particularly in the urban centres. ${ }^{4}$ Together with Finnish, Estonian, Karelian, and others, the Vepsian language belongs to the Finnic subgroup of the Finno-Ugric languages (Puura et al. 2013). It is the easternmost language of this subgroup, with Liv(onian) being the westernmost. There are, reportedly, three main Vepsian dialects - northern, central, and southern - which are all considered to be mutually intelligible (see Figure 1).

The Vepsian language has long been under the scrutiny of academics and policy-makers who have often pronounced it as doomed. Elias Lönnrot, the author of the Kalevala, wrote his dissertation on Veps, "Om det Nord-tschudiska språket" ("On the North-Chudic Language"), in 1853. Even at that point, he declared that Vepsian was a dying language (Strogal'shchikova 2008). Despite this information, some time passed before scholars tried to sustain Vepsian ways of speaking (and writing). I deliberately put "writing" in brackets since Veps used to engage with the world they lived in mostly through verbal interaction. Indeed, the first concrete attempts to codify and standardise Vepsian occurred only at the time of korenizatsiya (Indigenisation), when a group of scholars from the Leningrad Oblast, led by Nikolai Bogdanov, began collecting material on the Vepsian language and created a standard form of the language (Kettunen and Siro 1935; Salminen 2009; Setälä et al. 1951). In 1932 and 1936, the academics published the very first Vepsian textbook and Vepsian primer, respectively, in a Latin-based script, and a total of 53 primary schools and seven secondary schools were also opened (Strogal'shchikova 2008). Indeed, the Soviet aim to reach out to the various ethnic groups to 


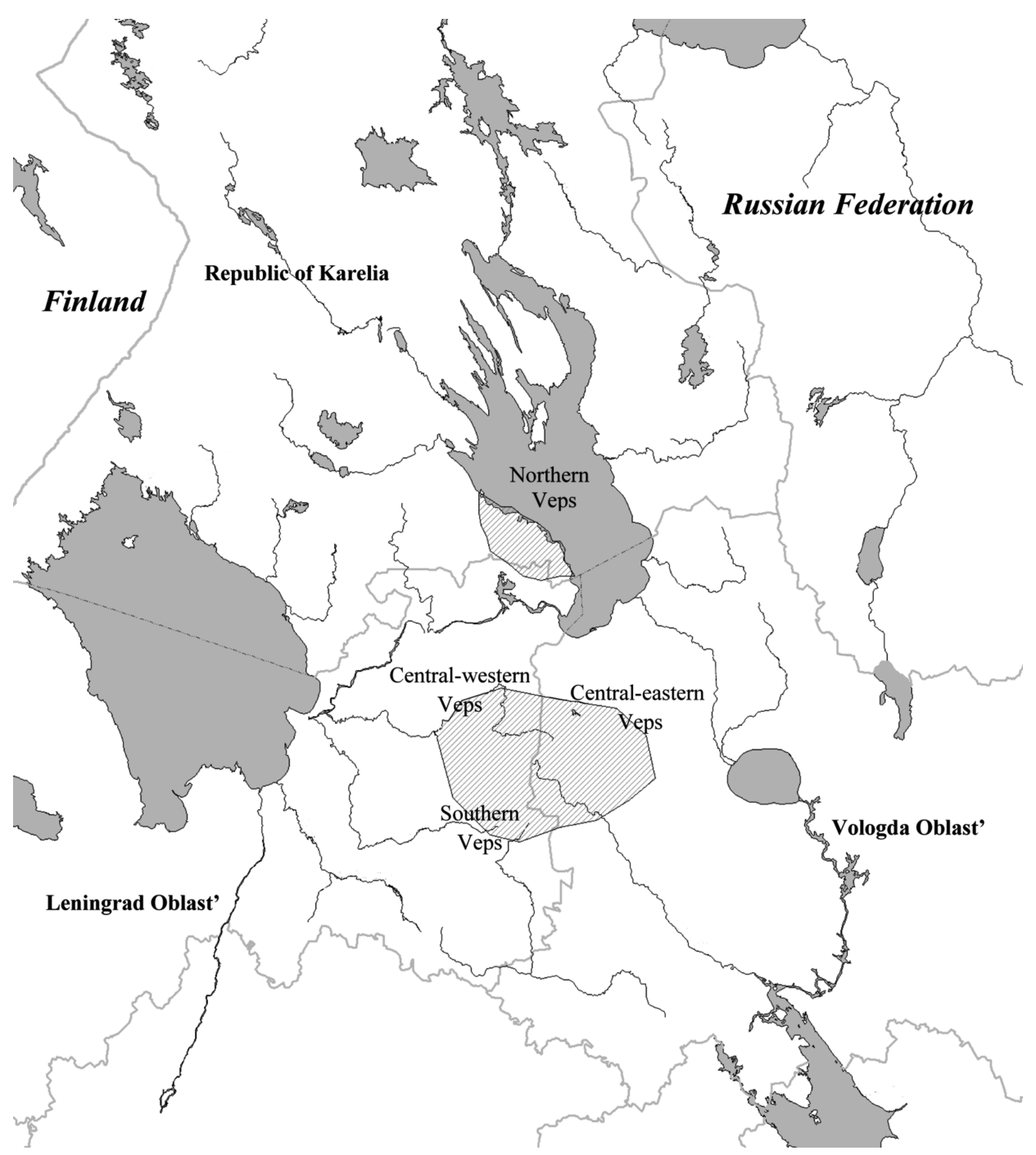

Figure 1: Location of the territory where the Veps live and the main Vepsian dialects (Mullonen 2012)

eventually form the "Soviet citizen" initially involved the creation of an alphabet and the creation of a standard language, followed by the production of teaching materials (Hirsch 2005; Laine 2001). Under the Soviets the peoples of the North had similar experiences in regard to literacy as they underwent a "glorious beginning in the 1930s interrupted by the war, then a strong continuation in the $1950 \mathrm{~s}$, then a drop in the $1960 \mathrm{~s}-70 \mathrm{~s}$, and a resurrection in the 1980s, interrupted by the economic crisis of the early 1990s" (Vakhtin 2005, 131). ${ }^{5}$ Vepsian writing also had a very short lifespan since it was banned at the peak of Stalin's terror in 1937.

Scholars and activists rekindled an interest in the Vepsian language a few decades later at the time of perestroika and glasnost. In the late $1980 \mathrm{~s}$, a group of young Veps, Ingrians, and Karelians together became interested in the Indigenous peoples of the Republic of
Karelia and their heritage languages with the belief that their intervention could prompt and sustain the use of these languages. Their interest and perseverance generated the revival of the Vepsian language and culture. The Vepsian revival movement officially began in 1987 with a festival called Elon pu / Drevo Zhizni (Tree of Life) in Vinnitsy in the Leningrad Oblast. The following year, the activists attracted the attention of the government in Moscow, which enabled them to organise a conference on the linguistic and socio-economic situation of Veps at the Academy of Sciences in Petrozavodsk (Klement'yev, Kozhanov, and Strogal'shchikova 2007). On this occasion, Zinaida Strogal'shchikova (2008) also founded the Society of Vepsian Culture. Thanks to the activities of the society, Veps received the political status of Indigenous peoples in Karelia. The activists had two main areas of operation: on the one hand, they focused 
on the political status of Veps within this multi-ethnic northwestern Russian territory; on the other, they promoted Vepsian heritage language by creating a new standard form. Strogal'shchikova and Nina Zaitseva respectively prompted, and still lead, these two overarching orientations within the movement. They aimed to simultaneously restore village life and sustain Vepsian ways of speaking, adding prestige with the promotion of Vepsian literacy. However, their requests to support village life were turned down by the political administration after the 1988 conference (Klement'yev, Kozhanov, and Strogal'shchikova 2007). The activists also faced an unsurmountable challenge, given that specific verbal interactions are continuously being created and occur mostly in rural areas where people engage orally in their heritage language with that environment and its human and non-human inhabitants. Questions and perplexities related to Vepsian language sustainability remain open, as the director of the Karelian Research Center of the Academy of Sciences in Petrozavodsk, Irma Mullonen, acknowledged during an informal discussion (Siragusa, field notes, 2014).

Inquiring about language sustainability is often viewed as being synonymous with inquiring about the generational transmission of a language. That is, evaluating if a language is sustainable generally means asking whether or not it is passed on from one generation to the next (Fishman 2001). Most worldwide revival programs show that taking this approach has at least two internal implications. First of all, it hints at a structural approach to language, often understood as a system of rules that can be transmitted generationally, and, second, it has a strong focus on the creation of a standard form for educational and publishing purposes (Hinton and Hale 2001; Hornberger 2008; McCarthy 2005). Academic figures, such as Joshua Fishman (2001), have developed best practices and specific sequential steps on how to guarantee the sustainability of a so-called endangered language. Such a course of action is also referred to as language planning. This sequential pattern offers rather strict consecutive steps beginning with the assessment of the language situation, moving into the expansion of language domains of use, and culminating with the minority language being mainstreamed into the education system (Fishman 2001, 466; Hinton and Hale 2001).

Consciously or not, the intervention of Vepsian activists has been greatly tied up with this model and the ideologies at which it hints. This pattern implies that literacy is a step further in the development of a language and that literacy should represent the ultimate goal to secure language sustainability. Admittedly, these ideologies are widely spread also in post-Soviet Russia, where it is often believed that an intervention from the authorities can induce social change and that literacy stands a step above orality in the hierarchy of a language (see also Reznik 2007 and Smith 1998 on the Soviet language politics promoted by Nikolay Marr). The ideological foundations intrinsic to this model are debatable. Indeed, they often disregard language ecology, communicative practices, and language as something that is created together and cannot be removed from life as an abstract system, the local and situated idiosyncrasies, and the economic challenges (Siragusa 2015).

Yet following these steps appears to have in some ways positively contributed to the Vepsian revival efforts. It has brought younger Veps closer to their heritage language, especially those who have grown up in an urban environment. Receiving Vepsian education has inspired some of them to carry on their revival endeavours, and the results have often been surprising. Having acquired knowledge of standard Vepsian, some former students at Petrozavodsk State University have decided to work for the available media channels, such as Vepsian radio and television. Some young Veps promote Vepsian music - for example, the Vepsian folk band, Noid - work for the Finno-Ugric magazine, Kipinä, or the monthly Vepsian newspaper, Kodima, and some conduct research on Vepsian matters at the Academy of Sciences. Admittedly, most of them live in the city and employ Russian ways of speaking to cover more domains in their daily life. Yet some former students move back to the villages and begin teaching Vepsian at the local schools and/or nurseries. This is particularly the case of those northern Vepsian villages, such as Sheltozero, Shoksha, and Rybreka, which obtained the official status of Vepsskaya volost' (Vepsian district) of Karelia in 1994 (Strogal'shchikova 2008). Furthermore, the research conducted by the students in the villages and in the archives have allowed them to rediscover obsolete words that the language activists later re-introduced in dictionaries and textbooks - such as, for example, izor (dear, favourite) and hangoine (fork) - hence, enhancing cooperation among the different parties involved in the revival efforts and securing the desired generational transmission and expansion of Vepsian domains of use.

In spite of the aforementioned positive results provided by the Vepsian Renaissance, the activists still face undeniable challenges. The economic situation that dominates rural areas has been the main concern - and perhaps this is rightly so. However, the recurrent discussion around difficult economic circumstances and the obstacles provided by denying and/or limiting investment in rural areas will not represent the main focus of my article, although I will make reference to it when 
necessary (Danilova 2008; Yakusheva 2008). Instead, I want to focus on other, less visible, challenges that more subtly affect these revival efforts, such as concealment practices. Among Veps, the use of secrecy is often intertwined with dynamics of power, and so I will now move on to discuss how secrecy is used in bilingual practices where speaking Russian becomes a register of avoidance and Vepsian is reinforced as the language of sacredness.

\section{Secrecy and Language Sustainability}

In his article "Secrecy," Graham Jones $(2014,53)$ provides an excellent synopsis of the literature that has been circulating in anthropology since secrecy became a "paradigmatically anthropological topic." Therefore, I will not reiterate what Jones has already done but will employ his work as the foundation from which my current analysis stems, as I show how inquiries around secrecy can link to questions related to language sustainability in the terms I have described above. In short, the questions I aim to unpack regard secrecy not only "as a reflection of epistemological and ethical dimensions of cultural anthropology" but also, adding ontological depth, as an engagement with language ecology more broadly (53). Consequently, I intend to demonstrate how secrecy enables us to further disclose the challenges and advancements provided by revival movements within a literacy-orality polarity.

The concept of secrecy already challenges us when trying to define it as a socially shared practice. First of all, as Michael Herzfeld $(2009,135)$ points out, revealing a secret is paradoxical per se since it "must itself be performed in a public fashion in order to be understood to exist." Consciously or not, when somebody reveals a secret, they alter its very significance. In fact, a secret can be already revealed physically through gestures and ways of handling one's body (Herzfeld 2009; Jones 2014; Rhine 2014). Besides this intrinsic paradox, secrecy is ambivalent in that it can provide both social benefits and disadvantages. Adopting secrecy can help regulate relations by creating intimacy and trust among individuals, and yet it can also instigate tensions and cause the breakdown of social and cultural reproduction (Siragusa, field notes, 2013, 2014; Debenport 2010; Ferme 2001). Indeed, employing concealment practices blend together social agreement and disagreement. Given such an entanglement, it is no surprise that secrecy can also act in favour of, or against, language sustainability efforts, as I reveal in the following sections. So, what does secrecy bring together? Concealment practices are interwoven with several genres of speech and non-verbal communication, such as silence, "whispers, rumours, shibboleths, lies, [and] confessions" (Allison 2011; Jones 2014, 57; Vallikivi 2012). Secrecy does not bluntly equal hiding information from a larger audience than the one targeted to share information, but it does draw in taboos, bilingual/plurilingual practices, and literacy-orality polarity in a given language ecology - all of these are highly convoluted in the revival discourse and paradigms of language sustainability. Bearing this in mind, I now present Vepsian rural and urban dwellers and the strategies that they often employ to maintain (but also to challenge) social order through secrecy - at times, matching the goals established by the language activists and, at other times, creating friction with it.

\section{Secret Oral Practices and Language Sustainability}

On a sunny and yet chilly summer day in 2010, Irina Baranova and I decided to meet up along the lakeside in Petrozavodsk, right before she departed for her holidays (Figure 2). Her daughter was away in the countryside with her grandmother, Irina's mother-in-law, and her husband had gone for some training outside of Karelia, all of which enabled her to have some spare time and join me for a cup of coffee. I had met Irina as soon as I arrived in Karelia in 2009. On top of her work, she was then leading a music ensemble, Vepsän Hel'm (Vepsian Pearl) at the Centre of National Cultures in Petrozavodsk. I was part of this ensemble and that is how I met her. Despite our frequent and regular rehearsals, we had not had the chance to get to know each other in much depth, and so, on this occasion, we took advantage of the quiet circumstances and disclosed parts of our life histories and personal objectives to one another.

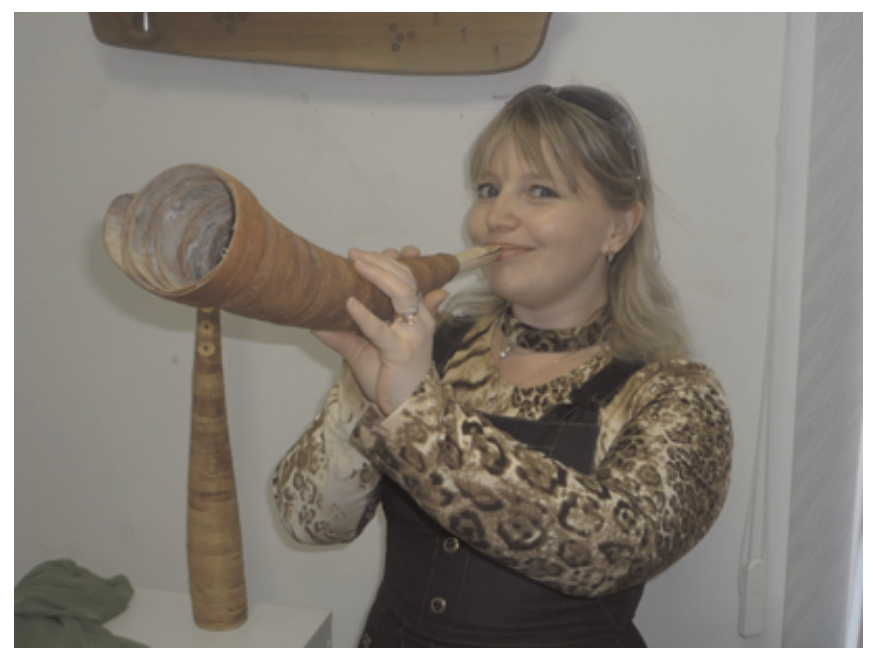

Figure 2: Irina Baranova at an exhibition on traditional music instruments of Karelia in Petrozavodsk in May 2010 (photo courtesy of the author) 
At the time, she was in her early thirties, working as a metodist (pedagogue, methodologist) at the Karel'skiy Institut Razvitiya Obrazovaniya (Karelian Institute for the Development of Education). She explained that her duties were to inform the teachers about Vepsian, Karelian, Ingrians, and other ways of living, traditions, and music since she was Vepsian herself and had been trained in such matters. Irina is originally from Voylakhta, a central Vepsian village in the Vologda Oblast. Her grandmother, who had just recently died, used to live there, and Irina, as a child and a young woman, used to visit her and spend most of her summer holidays in the village. She explained: "My grandmother could speak Vepsian and she often used it as a secret language, so that I could not understand what she was talking about. It was amazing how she could shift from one language to the other. Shame that she did not want to teach me! I asked her many times, but she insisted that I did not need it." 6 She continued: "I could understand some words when my grandmother was speaking Vepsian to her friends. But that was still not enough for me to learn it." In fact, what Irina told me has occurred to many other Veps of her age who were born in, or had moved to, the city with their family and only randomly (often in the summer) visited their grandparents in the village. This should not come as a surprise, given the policies of assimilation that followed Stalin. At the 22nd Party Congress in 1961, Nikita Khrushchev launched the policy of liquidation of the villages without prospects, which hugely affected the rural lifestyle not only of Veps but also of other villagers in Russia (Strogal'shchikova 2008; Yegorov 2006). Many Veps migrated to urban areas, thus leaving remaining villages further apart from each other. However, in the villages, people continued to use their heritage language orally as a form of engagement with that environment, its human and non-human inhabitants, and as a way to feel and share emotions. Here, the children/grandchildren (such as Irina) came in contact with those different ways of speaking and of engaging with the local environment that was obsolete in the city. Some of them expressed interest in rural life and wanted to learn more about it, but many did not, as Irina complained: "You see, I have seventeen cousins and I am the only one who wants to do something with our Vepsian roots. The others do not care. They speak Russian and think that they are Russian!"

It appears that her grandmother's strategies had proven successful, alas to the detriment of language sustainability. The scholars' and activists' desired generational transmission had been abruptly interrupted.
More specifically, what was interrupted was the joint creation (and consequent transmission) of a verbal and spontaneous interaction within the situated Vepsian language ecology and not the transmission of standard Vepsian, which the language activists soon developed and started to promote. However, I do not suspect that the actions of Irina's grandmother (and other elderly Veps) consciously aimed to damage their heritage language. Indeed, paradigms of language endangerment and language death have only recently and partially reached the villages where many rural dwellers are still convinced that Vepsian is widely spoken, even though they do not actively speak it to their own children or grandchildren. Many villagers assert that there are far more speakers than the statistical data show and are rather surprised when they hear otherwise. Strogal'shchikova conducted quantitative research in the villages and confirmed this to me. Some even claim that there are "thousands of speakers around the whole territory where Veps dwell" (Siragusa, field notes, 2010).

In fact, the Vepsian villagers have often adopted secrecy and employed concealment practices as a way of protecting and guaranteeing the well-being of their loved ones and certainly would not wish to harm them in any way. Secrecy has become a political action as it was the way of engaging with the local rural ecology; adopting certain ways of speaking as opposed to others has often conveyed positive connotations, aimed at ensuring the safety of the villagers from undesirable events. Vepsian village dwellers tend to believe that speaking their heritage language can influence life events, and, therefore, they use it very carefully (see also Debenport 2015; Finnegan 2007). A careful (at times, synonymous with secretive) use of Vepsian heritage language encompasses a social engagement among humans and between human and non-human beings, such as the spirits and the animals living in this territory. The Vepsian cosmology comprises several territory masters and hengid (spirits) in which Veps believe thus far, despite occasionally denying it. Most territory masters have a male ( $i \check{z}$ and) and female (emäg) aspect. The Vepsian word $i z \check{z}$ and means the master/head/host of the house, and it is found in many of the names of the spirits with which Veps interact, such as mecaižand (the host of the forest), vedenižand (the master of the water), pertinižand (the master of the house and land where the house is built), kül'betižand (the head of the Vepsian sauna), and so on (Strogal'shchikova 2008). In Pondala, a Vepsian village in the Vologda Oblast, the rural inhabitants also refer to the territory masters as toine pol' (the other half), indicating an equal and 
respectful relationship between humans and territory hosts (Vinokurova 2008). In order not to upset the territory masters and, most of all, the hengid, Veps pay them respect by being kind to the environment that they inhabit, by keeping their land well looked after, their houses tidy and clean, and by refraining from swearing. Aleksander Makeev, a Vepsian man living in Rybreka in the Republic of Karelia, once smirked as he told me: "We do not curse in Vepsian. There are no swearing words in our language. If we do need to swear, we use Russian words." His comments emphasise the verbal strategy aimed not to upset the environment in which he and the other villagers live. This also indicates how code-mixing and code-switching between Russian and Vepsian are convoluted in concealment practices. Veps believe that employing their heritage language can have a stronger and more powerful effect on life events and people's life trajectories, and, as a result, they can appropriately shift into a different mode of speaking, disguising the most powerful and sacred one, protecting themselves and those around them.

Veps tend also to apply a similar speech behaviour in their relations with non-human animals. Their verbal practices often show a twofold relation between humans and animals - one of trust and care and one of carefulness. On the one hand, through specific verbal practices, the villagers aim to protect the animals from unadvisable events and, on the other hand, the villagers perceive some animals as dangerous and explicitly avoid mentioning their names. This polarity in verbal practices echoes the overarching human-animal relations in place among Veps, which tend not to classify the animals as wild or tame. Rather, their classification often depends on the location where the animals usually reside, on their morphological characteristics, and on a symbolism influenced by the arrival of the Christian faith (Vinokurova 2006). Indeed, elements of pre-Christian faith have mixed with Christianity, which reached Rus' in 988 CE 988 with the conversion of Prince Vladimir and later reached Karelia in 1227 (Shubin 2004; Vikhoreva 2010). This implies that some animals are attributed specific connotations once they have gained a positive or negative reputation and that people engage with them accordingly in their speech and other social behaviours. Snakes, for example, are considered inhabitants of the netherworld, and their presence is believed to bring death to a household (Vinokurova 2006, 159-160). As a result of this belief, people prefer not to kill snakes as it would not be auspicious. Instead of killing them, any snakes found near houses are taken far away by villagers (Siragusa, field notes, 2013). If someone has been bitten by a snake, however, the villagers pursue help from the local tedai (the one who knows) or the noid (sorcerer), who can perform an enchantment (puheg) to save the individual from dealth (Siragusa, field notes, 2013-15; Arukask 2002).

Vepsian rural dwellers tend to ask for the help of the tedai for several reasons, such as choosing the land upon which to build their house, healing someone who has fallen ill, finding lost animals (often cattle in the forest or swamp), and protecting someone from the evil eye. ${ }^{7}$ I was kindly read a puheg against snake bites during my fieldwork in Kurba, a central Vepsian village in the Leningrad Oblast in the summer of 2013. During the puheg, the tedai does not mention the snake directly but refers to it as tühkjereine per-pereine, where the first word has no meaning and the second means that there is something behind the person who speaks (Siragusa, field notes, 2013). A researcher of Vepsian at the Academy of Sciences and a teacher of Vepsian at Petrozavodsk State University, Ol'ga Zhukova, helped me to translate and interpret this phrase. She further commented that tühkjereine per-pereine could also mean a nest of snakes. Indeed, Veps often avoid calling unfavourable animals by their name as this might turn against them. Instead, they can employ descriptions or paraphrases to address these animals. For example, villagers will call a bear käpš, sur' oc, mecižand, or bukač (paw, big forehead, master of the forest, or beech). ${ }^{8}$ Unsaid words, therefore, aim not to disrupt the allegedly regular course of life events and not to harm the environment as well as its residents. Whether or not they are efficacious is not the point of my research but, rather, how concealment practices have long aimed to protect people and the land in which they live and to which they relate (Piliavsky 2011).

Protecting loved ones by means of spoken (or unspoken) language became a necessity during Stalin's terror and in the years following. In the summer of 2013, I visited Nemzha, a central Vepsian village in the Leningrad Oblast. This is where I met Liudmila Ivanova (pseudonym). ${ }^{9}$ On a sunny afternoon, we sat together in her kitchen, and I listened as she recollected memories from her youth. She was now in her midseventies and remembered how in her youth her father was sent to Yakutia and never made his way back to the village. She disclosed: "They said he was a rich man and for this reason they took him away. How rich could he possibly be! We were just peasants. Yes, we had our cows ... in fact, they took another man who was living nearby. Well, they took everyone, every man!" I was told similar stories on several occasions. Some of the elderly villagers revealed how they themselves were deported or simply had to relocate to some remote village 
in the southern or eastern parts of the Soviet Union before coming back to this northwest region and resettling. Nonetheless, upon their return, people were not allowed to resettle in the village where they were born and/or had lived; they could only relocate somewhere else in the Republic of Karelia, Leningrad, or Vologda Oblasts (Siragusa, field notes, 2010, 2013). People began employing their heritage language carefully in the presence of others because they felt that speaking it could cause harm and injure their relatives and the other co-villagers. They feared that speaking their own language would put them in the spotlight and highlight their differences, showing them to be people who did not conform to the desired Soviet citizen.

Indeed, as we were travelling back from a festival in Oshta and driving through Sheltozero, Marina Ershova (pseudonym) pointed out her native village to me. When she was little, however, she moved to Vladivostok with her family and could only return to Karelia in 1964. While her parents were fluent speakers of Vepsian, she admitted finding Russian easier, given that since her childhood she had used it among her circle of friends and acquaintances. She explained that her parents used to employ Vepsian as a "pocket language" while they were living in Vladivostok, so that people could not understand what they were talking about. This linguistic strategy applied particularly to discussions around family matters, the economy, and so on. People often employed such precautious measures as a way to guarantee their safety in all spheres of life. Unmistakably and understandably, sustaining certain ways of speaking was not a priority for those who endured deportation, war, and hunger. These people's first concern was to protect their families from the risk of being deported and disappearing or from being ridiculed for their way of speaking, as was often the case even among Veps (Siragusa, field notes, 2010, 2013). ${ }^{10}$ In Pondala, Larisa Baburova (pseudonym) described how she went to school in Kuya, which is located many kilometres from her home village. As opposed to Pondala, which is surrounded mostly by forest and swamps, Kuya stretches along a lake, and, in the summer, many snakes make their way into the inhabited areas. Due to the frequency of snakes in this area, people have developed a different vocabulary to talk about them than that which is used in Pondala (Siragusa, field notes, 2013). At first, the children who came from Pondala to Kuya to study were not familiar with such a lexicon and were often mocked by their schoolmates as a result.

In short, for the elderly bilingual villagers, engaging in concealment practices has often meant shielding co-villagers and family members from danger and harm.
The use of secrets encompasses bilingual strategies that is, Veps often hid Vepsian away and openly spoke Russian as a less powerful language when dealing with spirits and non-human animals. They also employed Vepsian when sharing secrets and discussing topics that they did not want to be overheard by others. For many years, elderly Veps have not had to employ such strategies, and this has been detrimental to language reproduction and sustainability. This is partially due to the fact that paradigms and discourses of language sustainability have only randomly and recently made their way through to the villages. It is also due, however, to the fact that some elderly Veps generally look suspiciously at anything that comes from the city and the policymakers. Some villagers still question Vepsian education at school and are unsure of its benefits. They experienced Vepsian schooling in the early 1930s, and, after its abrupt ban in 1937, they were then punished for speaking it in class, during the breaks in the corridors, and generally among one another (Siragusa, field notes, 2010, 2013, 2014). Unsurprisingly, they demonstrated resistance and suspicion toward the activities of the administration in the city and its agenda. However, those young Veps who have benefited from Vepsian schooling and education at university have developed a different perception of the revival endeavours and have turned their recently acquired knowledge of Vepsian language to their advantage, as I intend to show in the next section.

\section{Concealment in Vepsian Literacy and Language Sustainability}

Upon my arrival to Petrozavodsk in 2009, my first acquaintances encouraged me to take part in the activities of the Centre of National Cultures, in the classes of Vepsian at the Finno-Ugric school, and at the Department of Finno-Ugric Languages at Petrozavodsk State University - all of which are situated in the city centre. I followed their advice, which proved to be a resourceful strategy, enabling me to open new doors for my research. ${ }^{11}$ I planned to generate a discussion around Vepsian use and revival by investigating bilingual practices, and so, during my first visits to these local institutions, I asked the students, activists, and teachers to participate in a language network exercise that I had developed before leaving for my fieldwork. The exercise invited them to reflect upon their bilingual communication practices, both in terms of speaking and writing activities. The idea was that they could draw several mind maps indicating a set of relations with their family members and other people during their daily activities in shops, schools, work, and so on (Figure 3). 


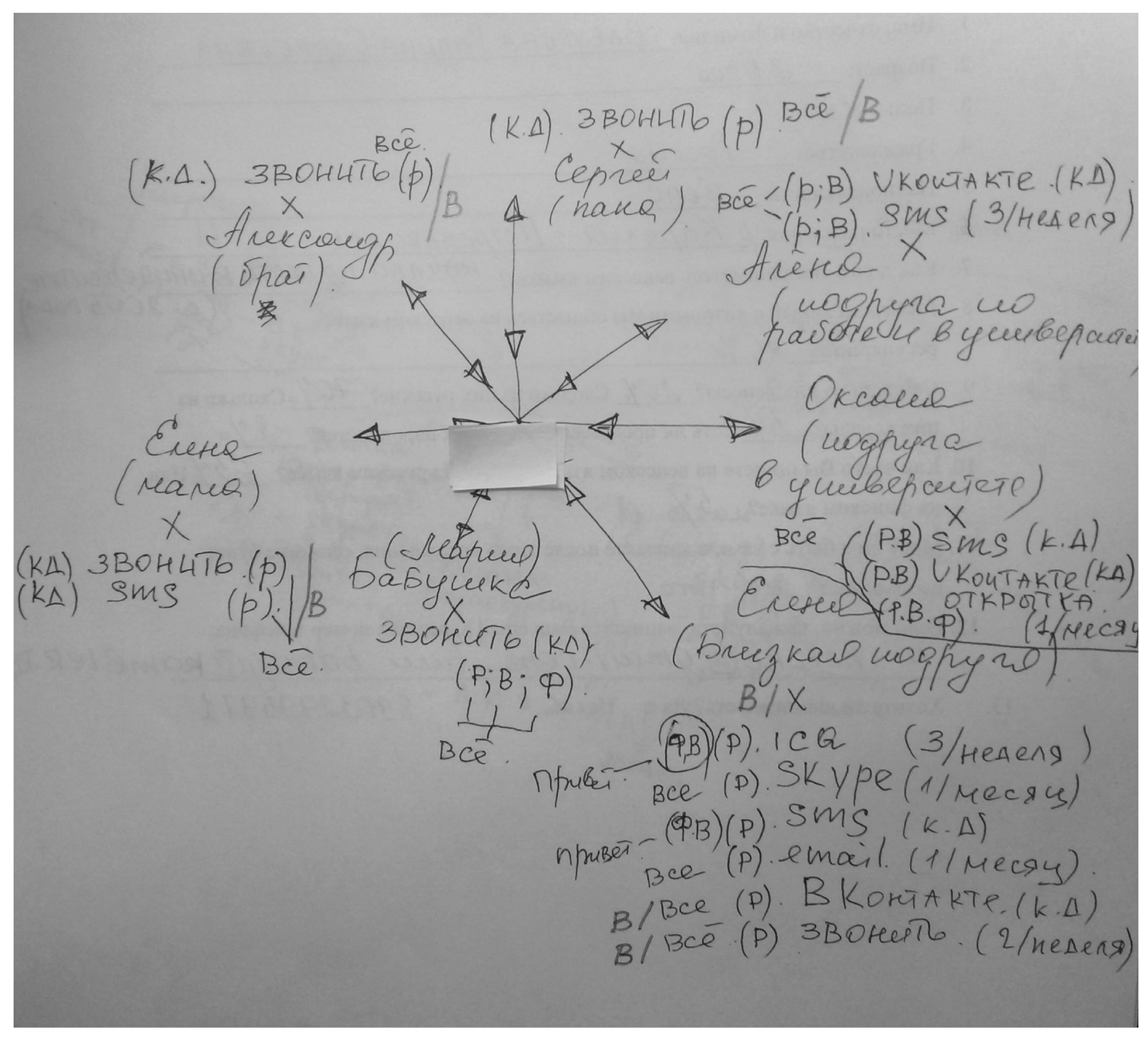

Figure 3: One mind map drawn by a student at Petrozavodsk State University in 2009 (photo courtesy of the author)

On 2 December 2009, I visited the fifth-year students of Vepsian, as previously arranged with their teacher, Ol'ga Zhukova. In the Vepsian classroom, I faced a group of six students in total, all of whom were girls (Figure 4). I presented the language network exercise, and they consented to complete their task, carefully indicating what language they employed when writing text messages to their friends on their mobile phones or on VKontakte (a Russian social network site equivalent to Facebook), when calling their grandparents, and when interacting among one another (Figure 3). Their practices showed uniformity; they mostly used Russian in their verbal practices and some Vepsian to greet and text their classmates or those they considered to be close friends. The choice to use Vepsian to greet someone with a text message indicated the desire to create a closer bond with the person to whom they were writing, who did not necessarily know the language. Thanks to modern technology, for these students Vepsian has become an inclusive and iconic language that can also reach out to those who would normally only speak Russian (McIntosh 2010, who makes similar remarks on the use of Kigiriama). In fact, this example reverses the status quo, which assumes the Vepsian language is backward compared to Russian, which is often associated with civilisation and culture (see also Eisenlohr 2004, 32). By adopting one of the most recent technological and advanced tools in the history of civilisation, the mobile phone (and I will soon show that this applies also to the computer), the students demonstrated that their language was up to modern standards. Here, Vepsian is not inferior to Russian anymore, since it has an alphabet that enables its use on the mobile phone and computer. The students, and Vepsian youth in general, write in Latin characters both when they employ Russian or Vepsian, often because it is cheaper not to employ Cyrillic characters (see also Horst and Miller 2006, 27-29; McIntosh 2010, 341). When writing in Vepsian, they do not need to adjust the Cyrillic characters, as they often do when writing in Russian and employing Latin 
characters (for example, the Cyrillic character "u," "ch" is often represented by "4" in text messages, due to their similar graphic appearance) (see also Crystal 2008, 124). In this context, Vepsian iconicity appears to be surpassing that of the Russian language as it indicates a proximity with other civilisations where Latin characters are used.

I soon discovered that there was one secret that the students had not revealed to me on their mind maps but that they disclosed orally to Ol'ga Zhukova as they were leaving the room. This was interesting because she was standing right next to me and so I could have easily heard them (and, in fact, did). However, I suspect that this was also their (sub)conscious intent since they did not object when Ol'ga Zhukova openly said: "Did you hear that? They write in Vepsian on VKontakte, so that people do not understand what they are talking about. They use it as their secret language among those belonging to their kruzhok (little circle)." At first, I thought that Ol'ga was referring to messages that people can send privately on VKontakte (just like on Facebook). However, as the students added me on to their pages on VKontakte, I soon realised that they also employed this bilingual strategy on their public walls that is, their "hidden" messages were disclosed to the public. All of a sudden, I found myself drawn into concealment practices that involved the use of Vepsian literacy as a means to share secrets by employing new technologies and trendy social network sites. ${ }^{12}$ Thus, to answer Susan Cook's $(2004,104)$ question - "do communication technologies change the way people speak/ write, or do these media reflect established patterns and norms of verbal interaction?" - the behaviour of the students conformed to what David Crystal (2001, viii) has already stated: "If the Internet is a revolution, therefore, it is likely to be a linguistic revolution." However, more than a sudden and dramatic revolution, such linguistic behaviours reflect a continuous negotiation with the present ecology where youth contribute to social change in small, often almost invisible, steps.

The students only partially revealed their "secrets," bringing to the surface a subverted Vepsian-Russian polarity (on similar considerations on race, see Kolko, Nakamura, and Rodman 2000). This secretive use of the language touched on inclusion/exclusion practices of bilingual writers, where one language is used to discriminate between others. However, this practice turned the usual unequal, accepted bilingual dynamics upside down, since it was usually the speaker of Vepsian who would shift into Russian ways of speaking to accommodate the other interlocutor(s). Writing in Vepsian, in this instance, did not diminish its power, as was the case in New Mexico, described by Erin Debenport
$(2015,13)$. Instead, what the students were doing broadened the domains of the language and added to its social value. ${ }^{13}$ Besides, such a practice involved the application of new technologies among youth, such as the computer and VKontakte, which empowered Vepsian literacy. ${ }^{14}$ As Aslihan Akkaya $(2014,285)$ notes, "it is social actors/ performers who mediate and negotiate (deploy and play with) various ideologies and semiotic resources in a given discursive encounter to accomplish artful performances," along with powerful socio-political connotations. Interestingly, the young students were all female, contradicting Lindsay Shaw and Larry Gant (2002) with regard to gender differences in information behaviour. Nonetheless, this is not surprising among Veps, where women outnumber men and are often the ones to determine social change.

Finally, the students also demonstrated independence in the promotion of Vepsian and did not rely on the momentum of the late 1980s movement. This last aspect appears to be of particular relevance as the literature has often criticised the adoption of new technologies in the promotion of a minority language. The main criticism is that the language activists and the population tend to rely on new technologies and transfer to them the full responsibility for the preservation of their heritage language (Dauenhauer and Dauenhauer 1998, 70; Eisenlohr 2004, 35-36). Rosemary Henze and Kathryn Davis (1999, 3-4) stress the importance of owning the media and using it for the promotion of language. In the case I have described, the students demonstrated that by adopting new technologies languages do not "die" but, rather, they continue to change and adjust to the ecology as life goes on. More recently, a young Vepsian activist from Sheltozero in the Republic of Karelia, Anna Ankhimova, has also been leading a project called Tervhen tulda vepsan male (Visiting the Vepsian Land), where she has developed interactive programs for iPads and iPods to learn Vepsian words, phrases, and common expressions as well as traditional ways of living in the countryside. Similarly, other Vepsian activists in their late twenties and early thirties are now promoting their heritage language on the radio, television, newspapers, and artistic films and documentaries.

The dichotomy of inclusion and exclusion encompasses a set of multiple relations co-evolving in social life that concern "the dynamic process of being shut out, fully or partially, from any of the social, economic, political or cultural systems which determine the social integration of a person in society" (Walker and Walker 1997, 8). Specifically, I am referring here to processes of partial inclusion/exclusion since the Vepsian youth allowed their readers to have access to their secrets, given that they wrote on their public walls on VKontakte, 


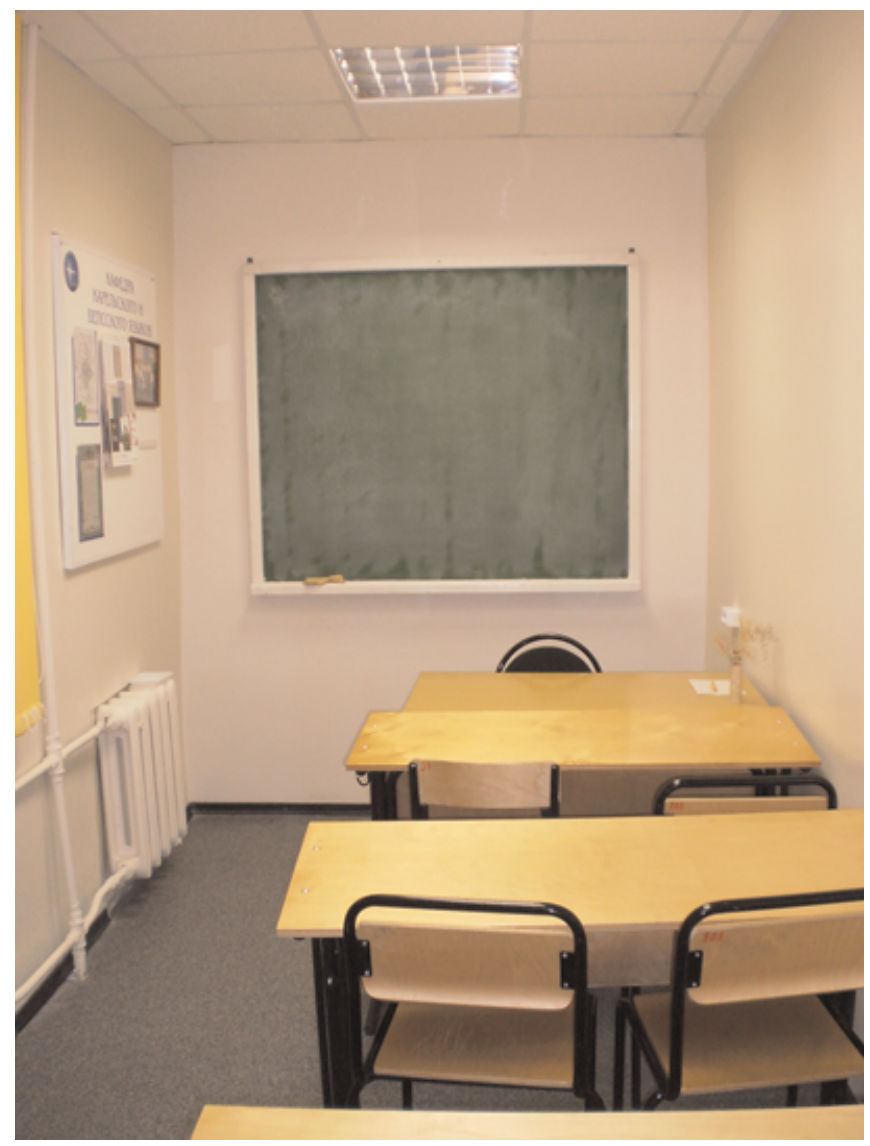

Figure 4: Vepsian class in room 302 at Petrozavodsk State University (photo courtesy of the author)

but they appeared to voluntarily discriminate between their readers since the messages were written in what appeared to be a "secret code" that only a few could decipher. Indeed, they did not translate what they were discussing into Russian, which usually happened in the presence of a non-speaker of Vepsian. In doing this, the students demonstrated the ability to turn secrecy from a social weakness into a strength through the use of the Vepsian written form. They displayed a skill that others did not possess and were proud of it, and they did not feel the need to hide it. Power relations of inequality were reversed in this case since those who generally dominated the public space linguistically were now marginalised and those who were forced to hide or to be ashamed of their knowledge of the Vepsian language could now freely demonstrate the ability to be proficient in it (Woolard and Schieffelin 1994, 56). As Jones $(2014,54)$ states, "secrets produce value through both the exclusion of outsiders and the inclusion of insiders." Through antipodal concealment practices, the students, and Vepsian youth in general, gained confidence (Luhrmann 1989), produced trust within their close circle of friends (Kaplan 2014), and, overall, actively and positively engaged with Vepsian literacy. Hence, they demonstrated the ability to sustain Vepsian through personal and social emotional empowerment strategies and in their ability to create new domains of Vepsian, thanks to newly acquired written skills.

Secrecy can therefore be interpreted here as being regenerative of Vepsian communicative practices (in this case, written), thanks to the emergence of new technologies. ${ }^{15}$ New domains are being created that correspond to new ways of engaging and interacting with the contemporary and always dynamic language ecology. Furthermore, the result appears to be counter-hegemonic, in that Vepsian gains a higher position in the hierarchy of languages, reinforcing its social prestige and increasing possibilities for its dynamic and interactive sustainability. Indeed, concealment appears crucial in the discourse around language sustainability when it is understood as a practice taken in order to subvert unequal social relations and to reinforce more prestigious social positioning of communicative practices. In this sense, language sustainability is tightly interwoven with secrecy as an ontological practice and can be assessed as successful not only because of its generational transmission but also because of its lively, dynamic, situated interaction with the overarching ecology in which people manifest language.

\section{Conclusion}

While not neglecting the complexity of other socioeconomic factors that hinder language revival movements, this article has focused on secrecy and the paradigm of language sustainability. Specifically, it has demonstrated how concealment practices are already complexly intertwined with models of language sustainability due to their intrinsic paradoxes. Indeed, secrecy touches upon taboos, bilingual practices, and a literacyorality polarity in a dynamic, situated, and interactive language ecology in which people dwell. This has involved showing how Vepsian urbanites and villagers have engaged in concealment practices and how these have matched (or not) the goals set by the Vepsian revival activists. In some cases, the practices appear to support and advance the revival efforts, while other instances appear to create friction with the revival movement. The situation appears less than straightforward since urban and village residents, as well as younger and elderly Veps, display multiple and varied relations toward the Vepsian revival as well as toward the environment and language ecology in which they dwell.

Elderly Veps, mostly inhabiting rural areas of northwestern Russia, tend to speak, and not to write, 
Vepsian. In this territory, Veps have developed a strong verbal connection with the environment, which encompasses humans, spirits, and non-human animals. Most of these Veps did not receive Vepsian education, and, if they did, this might have not lasted long because of the ban on Vepsian literacy in 1937, when they were children. Verbal interaction and socialisation also comprises concealment practices. It comes as no surprise that the elderly villagers employ concealment toward the spirits, which they believe live in the same territory as human and non-human animals; they use taboos, paraphrases, and bilingual strategies to secure their safety and guarantee the maintenance of social balance. Ensuring safety for loved ones and co-villagers became a necessity during Stalin's terror and the years following when subtle, but efficient, policies of assimilation were implemented. These behaviours only partially support revival goals and efforts due to resistance to Vepsian education, among other policies that emerge from, or are oriented to, urban environments.

Contrary to the situation of elderly Veps, Vepsian urban youth have grown together with the revival movement and have developed a deeper relationship toward Vepsian standard form. For this reason, they can more freely and independently engage with Vepsian literacy and turn it to the advantage of the Vepsian revival. In particular, they have combined concealment and literate practices, overturning dominant relations of power in the multi-ethnic territory in which they live. This has been possible, in part, due to the employment of new technologies, such as mobile phones, computers, and social networking sites, which have enabled young Veps to advance Vepsian literacy, increasing the hierarchy of the language. Partial dynamics of inclusion/exclusion have provided Vepsian ways of writing with prestige and social idiosyncrasies. In this sense, they have also displayed, consciously or not, agency toward language sustainability since they have created space for new domains for the use of Vepsian.

To conclude, this article has shown how relations between secrecy and language sustainability can be multilayered and complex. They can engage with the overarching language ecology while also hinting at different areas and ways of engaging with the language. The aim of this work has been to go beyond the usual discussion of economic influences on the Vepsian revival movement to examine more subtle, and yet still pertinent, factors that influence it.

Laura Siragusa, Department of Anthropology, School of Social Science, University of Aberdeen, Aberdeen, United Kingdom. Email: laura.siragusa@abdn.ac.uk.

\section{Acknowledgements}

This work was supported by the European Research Council Advanced Grant (Arctic Domus Project no. 295458), by the Estonian Ministry of Education and Research (IUT34-32), and by the Finnish Academy (HuSArctic). I am also extremely grateful to the two anonymous reviewers for their constructive and very useful comments.

\section{Notes}

1 I translated most passages from Russian. If otherwise, I will state it.

2 These observations are often applied to bilingual (and plurilingual) speakers, and, in this sense, Veps are no exception (see Aikhenvald 2003; Auer 1998; Rubino 2014; among others).

3 On literacy and bilingual practices, see also Sebba (2013).

4 Ingrians are Russian citizens with Finnic ancestors who moved to the territory around St. Petersburg in the 17th century.

5 The list of minority peoples of the North, Siberia, and the Far East comprises native peoples of Russia, counting less than 50,000 members. Evens, Itelmens, Khanty, Koryaks, Nenets, and Sami are just an example of those included in the list.

6 Debenport $(2015,5)$ illustrates how the elderly may strategically use the vernacular in front of the youth, but, in this case, the elderly want show them the importance of learning their heritage language. A similar description of bilingual practices is also given by Kulick (1992, 216). Although, in his description, the lingua franca becomes sacred and not the vernacular.

7 Arkhiv Karel'skogo nauchnogo tsentra (Archive of the Karelian Scientific Centre), file 19, tape 2662, no. 25; file 19 , tape 2663 , no. 22 ; file 25 , tape 3197 , no. 38 ; and file 25 , tape 3231, no. 44.

8 These terms are taken from the Vepsian film Živatad vepsläižiden elos [Animals in the Life of Veps], directed by Vladimir Slavov and Larisa Smolina, 2008.

9 I have employed pseudonyms where I consider the topic sensitive and/or if using real names will put the person with whom I interacted at risk. Some discussions took place spontaneously and informally, and I did not receive consent on whether I could make direct reference to the person when reporting their story.

10 On the employment of concealment for pragmatic reasons, yet causing confusion and ambiguity, see also Throop (2010, 155-156).

11 On the unpredictability that the researcher might face, especially at the beginning of his or her fieldwork, see Blommaert and Dong (2010).

12 The use of the concealment written practices that I am describing differ from the one Debenport $(2015,40)$ describes in regard to the production of dictionaries in Indigenous New Mexico, where "dangerous" and "secretive" practices are (but should not be) revealed through the written medium. However, her overarching analysis on the concealment practices in New Mexico as a way to control the circulation of information matches this strategic language use by the Vepsian students. 
13 Nonetheless, I should point out that those Vepsian elderly villagers who have knowledge of oral enchantments do not reveal them until they reach old age and want to pass this knowledge to someone younger. The reason for this is that they believe that such words once revealed would lose their power and capacity to influence life events. Codified Vepsian for the elderly is often perceived as a different way of speaking, and they do not relate closely to it and its social power.

14 On linguistic innovation by means of the computer, see Glowka, Melancon, and Wyckoff (2003); Baron (2002).

15 See also Herdt (1990) and Jorgensen (1990) on concealment practices as culturally regenerative.

\section{References}

Ahearn, Laura

2001 Invitations to Love: Literacy, Love Letters, and Social Change in Nepal. Ann Arbor: University of Michigan Press. http://dx.doi.org/10.3998/mpub.11264.

Aikhenvald, Alexandra

2003 Multilingualism and Ethnic Stereotypes: The Tariana of Northwest Amazonia. Language in Society 32(1):1-21. http://dx.doi.org/10.1017/ S0047404503321013.

Akkaya, Aslihan

2014 Language, Discourse, and New Media: A Linguistic Anthropological Perspective. Language and Linguistics Compass 8(7):285-300. http://dx.doi.org/

Allison, Jill 10.1111/lnc3.12082.

2011 Conceiving Silence: Infertility as Discursive Contradiction in Ireland. Medical Anthropology Quarterly 25(1):1-21. http://dx.doi.org/10.1111/j.15481387.2010.01123.x.

Arukask, Madis

2002 The Spatial System of Setu Kalevala-Metric LyricalEpic Songs. Tautosakos Darbai 17(24):46-64.

Auer, Peter, ed.

1998 Code-Switching in Conversation: Language, Interaction and Identity. New York: Routledge.

Baron, Naomi

2002 Who Sets E-mail Style? Prescriptivism, Coping Strategies, and Democratising Communication Access. Information Society 18(5):403-413. http:// dx.doi.org/10.1080/01972240290108203.

Blommaert, Jan, and Jie Dong

2010 Ethnographic Fieldwork: A Beginner's Guide. Clevedon, UK: Multilingual Matters.

Cook, Susan

2004 New Technologies and Language Change: Toward an Anthropology of Linguistic Frontiers. Annual Review of Anthropology 33(1):103-115. http://dx.doi.org/ 10.1146/annurev.anthro.33.070203.143921.

Crystal, David

2001 Language and the Internet. Cambridge: Cambridge University Press. http://dx.doi.org/10.1017/ CB09781139164771.

2008 Txtng: The Gr8 Db8. Oxford: Oxford University Press.
Danilova, Irina

2008 Traditsionnyy sotsial'no-ekonomicheskyy factor $\mathrm{v}$ sovremennom regional'nom razvitii vepsov: mera novatsii. In Vepsy: na rubezhe XX-XXI vekov. Z.I. Strogal'shchikova, ed. Pp. 127-142. Petrozavodsk: Karel'skiy Nauchnyy Tsentr i Ministerstvo Respubliki Kareliya.

Dauenhauer, Nora, and Richard Dauenhauer

1998 Technical, Emotional, and Ideological Issues in Reversing Language Shift: Examples from South East Alaska. In Endangered Languages: Language Loss and Community Response. L.A. Grenoble and L.J. Whaley, eds. Pp. 57-98. Cambridge: Cambridge University Press. http://dx.doi.org/10.1017/ CB09781139166959.004.

Debenport, Erin

2010 The Potential Complexity of "Universal Ownership": Cultural Property, Textual Circulation, and Linguistic Fieldwork. Language and Communication 30(3):204210. http://dx.doi.org/10.1016/j.langcom.2009.11.001.

2015 Fixing the Books: Secrecy, Literacy, and Perfectibility in Indigenous New Mexico. Santa Fe: SAR Press.

Eisenlohr, Patrick

2004 Language Revitalization and New Technologies: Culture of Electronic Mediation and the Refiguring of Communities. Annual Review of Anthropology 33(1):21-45. http://dx.doi.org/10.1146/ annurev.anthro.33.070203.143900.

Ferguson, Charles

1959 Diglossia. Word 15(2):325-340. http://dx.doi.org/ 10.1080/00437956.1959.11659702.

Ferguson, Jenanne

Forthcoming The Persistence of Antiquity: Language Ideologies and Perceptions of Language Vitality among Sakha Speakers. Journal of Multilingual and Multicultural Development.

Ferme, Mariane

2001 The Underneath of Things: Violence, History, and the Everyday in Sierra Leone. Berkeley: University California Press. http://dx.doi.org/10.1525/california/ 9780520225428.001.0001.

Finnegan, Ruth

2007 The Oral and Beyond: Doing Things with Words in Africa. Chicago: University of Chicago Press.

Fishman, Joshua, ed.

2001 Can Threatened Languages Be Saved? Reversing Language Shift, Revisited: A 21st Century Perspective. Clevedon, UK: Multilingual Matters.

Garner, Mark

2004 Language: An Ecological View. Oxford: Peter Lang.

Glowka, Wayne, Megan Melancon, and Danielle Wyckoff

2003 Among the New Words. American Speech 78(2):228232. http://dx.doi.org/10.1215/00031283-78-2-228.

Heath, Shirley

1983 Ways with Words: Language, Life and Work in Communities and Classrooms. Cambridge: Cambridge University Press. 
Henze, Rosemary, and Kathryn Davis

1999 Authenticity and Identity: Lessons from Indigenous Language and Education. Anthropology and Education Quarterly 30(1):3-21. http://dx.doi.org/ 10.1525/aeq.1999.30.1.3.

Herdt, Gilbert

1990 Secret Societies and Secret Collectives. Oceania 60(4):360-381. http://dx.doi.org/10.1002/j.18344461.1990.tb01561.x.

Herzfeld, Michael

2009 The Performance of Secrecy: Domesticity and Privacy in Public Spaces. Semiotica 175:135-162.

Hinton, Leanne, and Ken Hale, eds.

2001 The Green Book of Language Revitalisation in Practice. New York: Academic Press.

Hirsch, Francine

2005 Empire of Nations: Ethnographic Knowledge and the Making of the Soviet Union. Ithaca: Cornell University Press.

Hornberger, Nancy, ed.

2008 Can School Save Indigenous Languages? Policy Practice on Four Continents. New York: Palgrave Macmillan. http://dx.doi.org/10.1057/9780230582491.

Horst, Heather, and Daniel Miller

2006 The Cell Phone: An Anthropology of Communication. New York: Berg.

Jones, Graham

2014 Secrecy. Annual Review of Anthropology 43(1):53-69. http://dx.doi.org/10.1146/annurev-anthro-102313030058.

Jorgensen, Dan

1990 Secrecy's Turns. Canberra Anthropology 13(1):40-47. http://dx.doi.org/10.1080/03149099009508488.

Kaplan, Andreas M., and Michael Haenlein

2010 Users of the World, Unite! The Challenges and Opportunities of Social Media. Business Horizons 53(1):59-68. http://dx.doi.org/10.1016/ j.bushor.2009.09.003.

Kaplan, Danny

2014 The Architecture of Collective Intimacy: Masonic Friendship as a Model for Collective Attachments. American Anthropologist 116(1):81-93. http:// dx.doi.org/10.1111/aman.12070.

Kettunen, Lauri, and Paavo Siro

1935 Näytteitä Vepsän Murteista. Helsinki: SuomalaisUgrilainen Seura.

Klement'yev, Evgeniy, Aleksandr Kozhanov, and Zinaida

Strogal'shchikova, eds.

2007 Vepsy: modeli etnicheskoy mobilizatsii. Sbornik materyalov i dokumentov. Petrozavodsk: Izdaniye osushchestvleno pri finansovoy podderzhke sekretaryata Barentseva.

Kolko, Beth, Lisa Nakamura, and Gilbert Rodman

2000 Race in Cyberspace. New York: Routledge.

Kulick, Don

1992 Language Shift and Cultural Reproduction: Socialization, Self, and Syncretism in a Papua New Guinea Village. Cambridge: Cambridge University Press.
Laine, Antti

2001 Where East Meets West: The Last Stand of Finns and Karelians in Contemporary Karelia? Nationalities Papers 29(1):53-67. http://dx.doi.org/ $10.1080 / 00905990120036420$.

Luhrmann, Tanya

1989 The Magic of Secrecy. Ethos 17(2):131-165. http:// dx.doi.org/10.1525/eth.1989.17.2.02a00010.

McCarthy, Theresa, ed.

2005 Language, Literacy, and Power in Schooling. Mahwah, NJ: Lawrence Erlbaum Associates.

McIntosh, Janet

2010 Mobile Phones and Mipoho's Prophecy: The Powers and Dangers of Flying Language. American Ethnologist 37(2):337-353. http://dx.doi.org/10.1111/ j.1548-1425.2010.01259.x.

Moore, Kelly, and James McElroy

2012 The Influence of Personality on Facebook Usage, Wall Postings, and Regret. Computers in Human Behavior 28(1):267-274. http://dx.doi.org/10.1016/ j.chb.2011.09.009.

Mullonen, Irma Ivanovna

2012 Prirodnye i kul'turnye faktory formirovaniya vepsskoy etnicheskoy territorii. Trudy Karel'skogo nauchnogo tsentra RAN 4:13-24.

Mühlhäusler, Peter

2000 Language Planning and Language Ecology. Current Issues in Language Planning 1(3):306-367. http:// dx.doi.org/10.1080/14664200008668011.

Piliavsky, Anastasia

2011 A Secret in the Oxford Sense: Thieves and the Rhetoric of Mystification in Western India. Comparative Studies in Society and History 53(2):290-313. http://dx.doi.org/10.1017/ S0010417511000065.

Puura, Ulriikka, Heini Karjalainen, Nina Zayceva, and Riho Grünthal

2013 Case-Specific Report on Veps Language. Research Consortium ELDIA. Mainz: Studies in European Language Diversity.

Reznik, Vladislava

2007 Succession or Subversion: Professional Strategies of Soviet Cultural Revolution. The Case of Nikolai Marr. Slavonica 13(2):150-167. http://dx.doi.org/10.1179/ $174581407 X 228957$.

Rhine, Kathryn

2014 HIV, Embodied Secrets, and Intimate Labour in Northern Nigeria. Ethnos: Journal of Anthropology 79(5):699-718.

Rubino, Antonia

2014 Trilingual Talk in Sicilian-Australian Migrant Families: Playing Out Identities through Language Alternation. Basingstoke: Palgrave Macmillan. http:// dx.doi.org/10.1057/9781137383686.

Salminen, Timo

2009 In Between Research, the Ideology of Ethnic Affinity and Foreign Policy: The Finno-Ugrian Society and Russia from the 1880s to the 1940s. In The Quasquicentennial of the Finno-Ugrian Society (Suomalais-Ugrilaisen Seuran Toimituksia). Jussi Ylikoski, ed. Pp. 225-262. Helsinki: Société FinnoOugrienne. 
Sebba, Mark

2013 Multilingualism in Written Discourse: An Approach to the Analysis of Multilingual Texts. International Journal of Bilingualism 17(1):97-118. http:// dx.doi.org/10.1177/1367006912438301.

Setälä, Emil, Juho Kala, Emil Tunkelo, and Reino Peltola

1951 Näytteitä äänis- ja keskivepsäan murteista. Helsinki: Suomalais-Ugrilainen Seura.

Shaw, Lindsay, and Larry Gant

2002 Users Divided? Exploring the Gender Gap in Internet Use. Cyberpsychology and Behavior 5(6):517-527. http://dx.doi.org/10.1089/109493102321018150.

Shubin, Daniel

2004 From the Earliest Years through Tsar Ivan IV, vol. 1: A History of Russian Christianity. New York: Algora Publishers.

Siragusa, Laura

2015 Metaphors of Language: The Vepsian Ecology Challenges an International Paradigm. Journal of Estonian and Finno-Ugric Linguistics 6(1):111-137. http://dx.doi.org/10.12697/jeful.2015.6.1.07.

Smith, Michael.

1998 Language and Power in the Creation of the USSR, 1917-1953. Berlin: Walter de Gruyter. http:// dx.doi.org/10.1515/9783110805581.

Strogal'shchikova, Zinaida, ed.

2008 Vepsy: na rubezhe XX-XXI vekov. Po materyalam mezhregional'noy nauchno-prakticheskoy konferentsii 'Vepsy - korennoy malochislennyy narod Rossiyskoy Federatsii: perspektivy sokhraneniya i razvitiya'. Petrozavodsk: Karel'skiy Nauchnyy Tsentr i Ministerstvo Respubliki Kareliya.

2013 Vepsy: regional'nyye osobennosti etnodemograficheskikh protsessov 1930-2010 gody. In Läänemeresoome keeled, kultuurid ja kohavaim. Pribaltiysko-finskiye yazyki, kul'tury i genius loci. Pühendatud professor Tiit-Rein Viitso 75, sünnipäevale. Eva Saar and Ergo-Hart Västrik, eds. Pp. 117-119. Tartu: Kirjastaja.

Throop, Jason

2010 Suffering and Sentiment: Exploring the Vicissitudes of Experience and Pain in Yap. Berkeley: University of California Press.

Vakhtin, Nikolay

2005 Two Approaches to Reversing Language Shift and the Soviet Publication Program for Indigenous Minorities. Inuit Studies 29(1-2):131-147. http:// dx.doi.org/10.7202/013936ar.
Vallikivi, Laur

2012 Words and Silence: Nenets Reindeer Herders' Conversion to Evangelical Christianity. $\mathrm{PhD}$ dissertation, Cambridge University.

Vikhoreva, Irina

2010 La regione della Carelia e l'isola Kiži: Tesi di Laurea. Roma: Faculty of Science, Sapienza University of Rome. http://kizhi.karelia.ru/library/la-regione-dellacarelia-e-lisola-kizi-tesi-di-laurea (accessed 28 January 2015).

Vinokurova, Irina

2006 Zhivotnye v traditsionnom mirovozreniye vepsov. Petrozavodsk: Izdatel'stvo PetrGU.

2008 Vepssko-karel'sko-russkie kontakty v Babaevskom i Vytegorskom rayonakh Vologdskoy Oblasti (po dannym narodnoy demonologii). In Granitsy i kontaktnye zony v istorii i kul'ture Karelii i sopredel'nykh regionov. Gumanitarnye issledovaniya. Vyp. 1. O.P. Plyukha and I.I. Mullonen, eds. Pp. 104 115. Petrozavodsk: Karel'skiy nauchnyy tsentr RAN.

Walker, Alan, and Carol Walker

1997 Britain Divided: The Growth of Social Exclusion in the 1980s and 1990s. London: Child Poverty Action

Wedin, Åsa Group.

2013 Letters, Authority and Secrecy: The Case of Karagwe in Tanzania. Language and Education 27(1):44-58. http://dx.doi.org/10.1080/09500782.2012.679000.

Woolard, Kathrin, and Bambi Schieffelin

1994 Language Ideology. Annual Review of Anthropology 23(1):55-82. http://dx.doi.org/10.1146/ annurev.an.23.100194.000415.

Yakusheva, Vera

2008 Sotsial'no-ekonomicheskoe polozhenie vepsov Podporozhkogo munitsipal'nogo rajona. In Vepsy: na rubezhe XX-XXI vekov. Z.I. Strogal'shchikova, ed. Pp. 109-116. Petrozavodsk: Karel'skiy Nauchnyy Tsentr i Ministerstvo Respubliki Kareliya.

Yegorov, Sergey

2006 Vepsko-Russkoe mezhetnicheskoe vzaimodeystviye. In Sovremennaya nauka o Vepsakh: dostizheniya i perspektivy (pamyati N. I. Bogdanova). G.V. Kozlova, ed. Pp. 237-250. Petrozavodsk: Karel'skiy nauchniy tsentr RAN. 